\title{
Problem Doktrin Keagamaan Dan Fundamentalisme Dalam Membangun Budaya Multikultural
}

\author{
Kiki Mikail \\ Universitas Islam Negeri Raden Fatah Palembang \\ E-mail: kiki.mikail_uin@radenfatah.ac.id
}

\begin{abstract}
Religious teachings always teach and want peace and prosperity for every human being, both life in this world and in the hereafter. However, in social reality, it is found in behavior as well as limited discourse and understanding, attitudes that are counter peace and welfare. Truth claims and absolute validity are often used as a basis for legitimacy to aggress the beliefs of other religions.
\end{abstract}

Keywords: Diversity and fundametalism

\section{Pendahuluan}

Konflik dan pertikaian tidak hanya terjadi pada masyarakat majemuk, namun dapat terjadi pula pada masyarakat yang relatif homogen. Namun demikian, memang benar bahwa dalam masyarakat majemuk akan lebih sering mengalami konflik daripada masyarakat homogen.

Masyarakat yang relatif homogen seperti Jepang misalnya (Al-Munawar, 2004) "hampir tidak pernah terjadi konflik antar suku". Berbeda dengan masyarakat Indonesia yang terdiri dari beragam kelompok agama, etnik, dan tradisi. Kemajemukan seperti ini kemudian diperparah oleh kesenjangan sosial dan ekonomi yang tajam dan belum tumbuhnya budaya multicultural yang oleh banyak pihak diyakini lebih memungkinkan akan terjalinnya kerjasama dan kemitraan yang tulus.

Terlepas dari realitas keberagaman yang ada di Indonesia serta instrumen-intrumen sosial dan ekonomi yang dalam banyak hal juga sering memperkeruh suasana, ternyata konflik antar umat beragama juga sering muncul akibat ketidakpahaman atau terbatasnya pemahaman pemeluknya terhadap ajaran agama tersebut yang kemudian secara action menjadi sikap fanatisme yang sempit..

\section{Makna Multikultural}

Secara etimologis, multikulturalisme banyak digunakan di Kanada pada kisaran tahun 1950-an. Menurut Longer Oxford Dictionary, istilah multiculturalism merupakan derivasi dari kata multicultural. Kamus ini menyitir kalimat dari surat kabar Kanada,

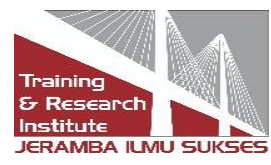


Montreal Times yang menggambarkan masyarakat Montreal sebagai masyarakat Multikultur dan Multilingual (Muhaimin 2004, hlm. 4).

Dalam Bahasa Indonesia, kata multicultur diterjemahkan atau diartikan banyak kultur. Tetapi istilah multicultur ini diambil dari Kanada yakni multiculturalism yang digunakan untuk mendukung makna yang sama dari pluralism dan perbedaan dimaksud terjadi karena perbedaan negara yang menerapkan prisinsip tadi. Misalnya di Amerika Serikat, menggunakan sebutan melting pot sociaty. India menggunakan ungkapan composite sociaty, di Indonesia sendiri menggunakan istilah bhineka tunggal $i k a$ (Ismail 2000, hlm.127). Pendapat ini didukung oleh Sal Murgiyanto yang mengutip Moore, "Jika multikulturalisme Amerika disepakati dengan popular sebagai melting pot, maka multikulturalisme Kanada dibandingkan dengan sebuah kebudayaan salad, dalam suatu tempat setiap komponen mempertahankan citarasanya" (Rahze 1999, hlm. 75), sedangkan multikulturalisme Indonesia tercermin pada moto "Bhineka Tunggal Ika atau bersatu dalam keanekaragaman" (Rahzeh 1999, hlm. 75).

Menurut Mugiyanto, dengan mengutip definisi William Davis, multikulturalisme adalah, " ... sebuah filosofi yang berarti berbagi dan membentuk bersama-sama. Objektivitas umum harus merupakan sebuah keinginan dan pertanggujawaban terhadap bagian dari sebuah kelompok untuk mengerti dan menghargai kontribusi orang lain terhadap kemampuan umum (Rahzeh 1999, hlm. 74).

Dalam wacana tentang pendidikan multikultural, secara sederhana istilah pendidikan multikultural dapat didefinisikan sebagai "pendidikan untuk atau tentang keragaman kebudayaan dalam meresponi perubahan demografis dan kultural lingkungan masyarakat tertentu atau bahkan dunia secara keseluruhan" (Muhaimin 2004, hlm. 4). Sebuah definisi yang sangat menarik karena terkandung makna adanya kerja keras dalam memahami perbedaan atau keragaman.

\section{Doktrin Keagamaan}

Pada setiap agama, khususnya agama-agama samawi, ditemukan adanya doktrindoktrin kebenaran mutlak sepihak atau doktrin yang mengklaim bahwa selain keimanannya adalah keliru. Doktrin eksklusif tersebut merupakan landasan iman yang mengikat pemeluknya untuk tetap eksis dalam keyakinan tersebut. Agama tanpa doktrin eksklusif juga tidak memiliki basis iman yang kuat. Oleh sebab itu, klaim tersebut dapat dipahami sebagai suatu keniscayaan dalam ajaran agama-agama, namun tidak harus dipahami secara tidak proporsional.

Untuk merujuk kepada contoh doktrin agama tersebut dapat dilihat pada beberapa ajaran agama, misalnya ajaran Kristen yang menjelaskan bahwa Yesus diakui sebagai satu-satunya jalan keselamatan. "Akulah jalan kebenaran dan hidup. Tidak ada seorang pun yang datang kepada Bapa, kalau tidak melalui Aku." (Yohannes 14:6). Ayat ini secara literal menjelaskan bahwa jalan satu-satunya kebenaran adalah beriman kepada Yesus. "Dan keselamatan tidak ada di dalam siapa pun juga selain di dalam Dia, sebab di bawah kolong langit ini tidak ada nama lain, maka terkenallah istilah No Other Name

Published by:

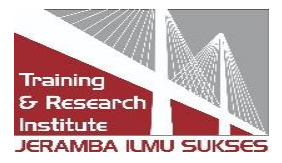


yang diberikan kepada manusia yang olehnya kita dapat diselamatkan." (Kisah Para Rasul 4 : 12). Akhirnya istilah No Other Name tersebut menjadi simbol tentang tidak adanya keselamatan di luar Yesus Kristus.

Sikap eksklusif dalam beragama sebagaimana pandangan Bishop menekankan bahwa hanya ada satu agama yang benar dan pada akhirnya akan menguasai dunia. Seperti yang diperlihatkan penganut Kristen bahwa agama Kristen akan menundukkan dan menggantikan seluruh agama lain di muka bumi ini karena Kristen adalah universal, absolut, kekal yang mampu mewujudkan keselamatan. Yesus bertahta di atas segala manusia dan dewa-dewa. Yesus tidak akan pernah diungguli (Amin Abdullah, 2000:117-118).

Rev. A. Gmeiner (dalam Amin Abdullah, 2000:118) juga menegaskan bahwa adanya usaha penyatuan keluarga umat manusia dengan berkat Tuhan berdasarkan kesatuan agama, saatnya akan tiba, semua manusia akan mengakui telah ditakdirkan tempat tinggal mereka yang selamat di bawah lindungan Tuhan yang namanya sudah dikenal seluruh dunia, yaitu "The Holy Catholic Church".

Dalam ajaran Islam, hal yang sama juga ditemukan di dalam Kitab Suci Al-Qur'an. Misalnya, firman Allah dalam surah Ali Imran ayat 9 sebagai berikut: "Sesungguhnya agama (yang diridhai) di sisi Allah hanyalah Islam. Tiada berselisih orang-orang yang telah diberi al-Kitab kecuali sesudah datang pengetahuan kepada mereka, karena kedengkian (yang ada) di antara mereka. Barang siapa yang kafir terhadap ayat-ayat Allah maka sesungguhnya Allah sangat cepat hisab-Nya."

Dalam ayat ini dikemukakan bahwa agama yang diterima Allah adalah agama Islam. Dengan demikian, kepercayaan di luar Islam merupakan suatu kekeliruan. Universalitas Islam tersebut diungkapkan oleh Muhammed Alexander Russel Webb (dalam Amin Abdullah, 2000:119) sebagai, "Tidaklah beriman seseorang di muka bumi ini bilamana ia tidak menyakini bahwa Islamlah pada akhirnya akan menjadi agama universal.

Masing-masing pemeluk agama, terutama agama misi, mencoba menawarkan keselamatan yang ia yakini kepada sebanyak mungkin manusia, termasuk kepada manusia yang telah menganut agama tertentu. Ajakan misi tersebut bukan hanya sebagai kesadaran ingin menyelamatkan manusia di dunia dan di akherat, tetapi juga bagian dari ajaran agama tersebut. Misalnya, agama Kristen dengan misi penyelamatannya dan Islam dengan dakwah amar ma'ruf-nya berupaya menyeru manusia sebanyak mungkin kepada agama masing-masing agar terselamatkan dan lepas dari api neraka. Hal itu merupakan upaya normal dari pemeluk agama jika ditinjau dari perspektif teologis, namun ketika ajakan itu dilakukan secara ekstrim dan tipu daya tentunya dapat menyebabkan benturan dan bencana kemanusiaan. Implikasi yang akan dimunculkan dengan cara-cara tersebut tidak lain adalah konflik agama.

Kendatipun, truth claim dapat dimaklumi doktrin eksklusif dalam ajaran agama-agama, tetapi pemahaman skripturalisme eksklusif dan literalis terhadapnya dapat menutup

Published by:

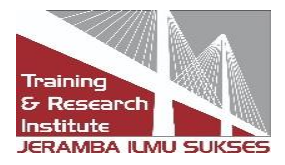


kesadaran terhadap pluralisasi agama merupakan suatu petaka bagi kehidupan sosial dan kemanusiaan dalam masyarakat global. Pemahaman literal terhadap doktrindoktrin eksklusif tersebut menjurus kepada sikap fundamentalis dan radikalis. Akibatnya, yang terlihat dalam sejarah umat manusia adalah terciptanya disharmonisitas dan konflik horizontal yang berkepanjangan dalam masyarakat agama sebagaimana yang terjadi pada era Perang Salib. Oleh sebab itu, cita-cita terdepan dari agama-agama untuk mensejahterakan dan menyelamatkan manusia di dunia dan akhirat akan berbalik menjadi bencana dan petaka kemanusiaan

Pada era modern, fundamentalisme mempunyai citra negatif bagi kehidupan masyarakat plural, sebab implikasi sosial dan politis yang diperankannya selalu bersifat destruktif dan a sosial. Karenanya, fundamentalisme sering dipahami secara pejoratif seperti fanatik buta, anti intelektualitas, eksklusif dan menyimpang dari keagamaan mainstream.

Klaim fundamentalisme muncul di dunia Barat Kristen disebabkan adanya kesenjangan literalitas doktrin agama dengan penemuan ilmiah. Keyakinan bahwa ajaran Bible tidak dapat salah sering bertentangan dengan penemuan ilmiah. Sebagai contoh dapat dilihat pada kasus penerimaan teori evolusi yang begitu cepat, di dalam maupun di luar kalangan biologi dirasakan mengancam keyakinan Kitab Suci yang menjadi dasar teologi Kristen (Riyal Ka'bah, 1993:25). A.S Peake (tt. : 323) mengatakan bahwa Abad ke 19 merupakan perjuangan sengit antara teologi dan ilmu, bahkan terhadap ajaran Kristen itu sendiri. Berdasarkan kenyataan demikian, munculnya gerakan fundamentalisme di dunia Kristen lebih disebabkan faktor internalitis ajaran Bible dalam pemahaman pemeluknya, ketimbang eksternalitasnya.

\section{Fundamentalisme Kristen}

Rifyal Ka'bah (1993: 27-28) mencatat bahwa fundamentalisme dalam agama Kristen dapat dijelaskan dalam empat hal. Pertama, fundamentalisme menganggap teks Bible mempunyai pengertian mutlak, jelas dan tidak berubah. Bible tidak memerlukan interpretasi atau pemahaman lain selain yang tersurat pada teks. Sebenarnya, hal ini pun tanpa disadari telah menjurus atau mengarahkan orang untuk masuk ke dalam sebuah penafsiran terhadap Bible itu sendiri. Namun mereka menganggap hal itu adalah satu kebenaran dan satu-satunya tafsir. Diskusi apa pun tentang Bible tidak akan mendapat kemajuan, sebab sejak semula mereka sudah menolak membicarakan teksteks tersebut.

Kedua, kaum fundamentalis, sebagaimana yang dikemukakan Eugne Laverdiers, melihat ungkapan Bible sebagai satu-satunya ukuran kebenaran. Oleh sebab itu, teks Bible mendahului segala-galanya. Dengan demikian, mereka kaum fundamentalis mengingkari kemungkinan berkembangnya wahyu dalam sejarah. "Bagi mereka teks Kitab Suci tidak mewakili suatu penyelidikan untuk pemahaman di mana iman mencapai Tuhan dan membuka diri-Nya untuk wahyu secara progresif" (Eugne, 1983:5-7).

Published by:

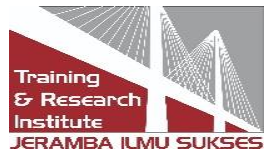


Ketiga, kaum fundamentalis menyangkal segi manusiawi dalam ungkapan Bible. Kaum ini tidak mengimani bahwa Kitab Suci tak ubahnya pribadi Jesus Kristus itu sendiri yang terdiri dari unsur manusia dan Tuhan. Ini berbeda dari kepercayaan umum Kristen yang berpendapat bahwa penulisan Bible juga memantulkan pandangan keduniaan tertentu, seperti juga kepercayaan, perasaan manusiawi, dan gaya bahasa penulis-penulisnya.

Keempat, penafsiran kaum fundamentalis sering berhubungan dengan pandangan ramalan (apocalyptic view). Hal inilah yang mendorong kebanyakan orang berpendapat, kaum fundamentalis sulit terpisahkan dari ramalan-ramalan. Kejadian di dalam dunia ini lebih banyak dilihat sebagai ancaman dan keputusan Tuhan, sehingga tidak membuka banyak pintu bagi manusia menyalurkan aspirasinya lebih bebas. Fundamentalisme juga berarti oposisi gerejawan ortodoks terhadap sains modern ketika terjadi pertentangan dengan Bible. Kaum ini mengklaim bahwa kalangan modernis sebagai perusak agama Kristen dan mengorbankan Kitab Suci demi kepentingan sains.

\section{Fundamentalisme Islam}

Sebagian penulis muslim berpendapat bahwa Islam tidak mengenal istilah fundamentalisme sebagaimana yang berkembang di dunia Barat Kristen. Hal ini dapat dibuktikan secara historis dan latar belakang munculnya fundamentalis tersebut. Munculnya fundamentalisme di dunia Kristen, sebagaimana yang telah dikemukakan, lebih banyak disebabkan pertentangan antara ilmu pengetahuan dan doktrin agama. Hal ini tidak terjadi dalam Islam, sebab dalam kesejarahannya Islam tidak pernah menentang temuan-temuan ilmiah, bahkan lebih jauh ia merupakan agen kebangkitan ilmu pengetahuan dunia.

Istilah ini dipakai secara intensif di Barat pada tahun 1980-an untuk memberi gambaran negatif terhadap Islam. Oleh Fredric M. Denny (dalam Riffat Hassan, 1993:32) dikemukakan bahwa penggunaan istilah fundamentalis dewasa ini lebih populer dipakaikan untuk kaum muslimin militan konservatif. Namun beliau mengakui bahwa hal itu adalah sesuatu kekeliruan jika mengacu kepada pengertian orisinil. oleh Bernad Lewis (1988:117) ditegaskan pula bahwa penggunaan istilah fundamentalis telah berlaku umum, tidak saja dipakaikan untuk kalangan Kristen tetapi juga untuk kelompok radikal dan militan lainnya. Walau demikian, beliau juga menegaskan bahwa penggunaan istilah tersebut bagi Islam dapat menyesatkan. Lebih tegas lagi Sayyed Hossein Nasr (1984:279-280) menyatakan; "Sejauh menyangkut fundamentalisme, penggunaan istilah tersebut oleh para jurnalis dan bahkan para ahli Islam yang ditujukan kepada suatu fenomena pemikiran Islam yang luas dalam dunia Islam saat ini sangat disayangkan dan menyesatkan, sebab istilah tersebut muncul dari konteks umat Nasrani, dimana konotasinya benar-benar berbeda". Fundamentalisme dalam lingkup agama Nasrani, khususnya di Amerika Serikat, menunjuk kepada bentukbentuk konservatif Protertanisme, yang biasanya anti kepada kaum modernis, dengan interpretasi yang sedikit literal dan terbatas kepada Kitab Injil dan sangat menekankan

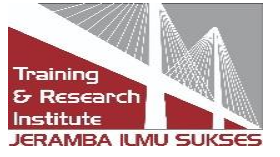


etika tradisional Kristen. Pemakaian istilah dan klasifikasi fundamentalisme secara luas pada sejumlah fenomena dan kecenderungan di bawah sebuah nama yang menyesatkan itu, hasil dari beberapa studi terhadap Islam saat ini membawa penyembunyian kenyataan keterlibatannya yang sangat dalam, meliputi fakta esensial tentang apa yang banyak tersebut sebagai Islam fundamentalis, yang anti tradisional dan tidak setuju kepada semangat dan isi tradisi Islam, seperti yang dimaksud dan dipraktekkan sejak turunnya wahyu Al-Qur'an.

Azyumardi Azra (1993:3) dalam salah satu tulisannya kelihatannya cenderung menyepakati istilah fundamentalisme terhadap gerakan Islam radikal. Beliau beranjak dari karekteristik fundamentalisme yang ditemukan dalam Dunia Barat Kristen ditemukan juga pada fundamentalisme Islam. Azra melihat hal itu dari ide dasar yang terkandung dalam istilah fundamentalisme tersebut, yaitu kembali kepada dasar-dasar agama secara penuh dan literal, bebas dari kompromi, penjinakan, dan reinterpretasi.

Dalam Islam, beriman secara fundamental, dalam arti etimologis, adalah suatu kewajiban, sebab setiap muslim diharuskan untuk meyakini dan menjalankan dasardasar agamanya. Tetapi, bersikap sebagaimana sikap fundamentalis dalam pengertian gerakan atau pengamalan radikal-destruktif terhadap persaudaraan manusia adalah sikap berlebihan dan berseberangan dengan mainstream doktrin Islam itu sendiri, sebab kedatangan Nabi Muhammad adalah untuk menjadi rahmat seluruh alam tanpa menafikan kemajemukan keyakinan dan agama yang dianut manusia.

Dalam pengamatan para ahli, pada era kontemporer fundamentalisme menggejala jauh lebih kuat di kalangan kaum muslimin dibandingkan dari kalangan penganut agamaagama lainnnya. Namun, hal ini tidak serta merta hanya dipicu pemahaman terhadap ajaran-ajaran agama semata, melainkan juga oleh faktor eksternal seperti diskriminasi dan hegomonisasi sosial, ekonomi, dan politik, sebagaimana yang terjadi di Palestina, Afganistan, Irak, Iran, Filipina, India, dan lainnya. Sebab, jika ditinjau secara keseluruhan, ajaran Islam sangat mementingkan perdamaian, kesejahteraan, keselamatan, dan persaudaraan sesama umat Islam dan sesama manusia. Hal ini diperkuat pula oleh sejarah Islam itu sendiri terhadap doktrin ajaran agama tersebut dengan merujuk kepada bukti hubungan antar sesama penganut agama yang diperankan oleh Rasulullah di negara Islam Madinah. Oleh sebab itu, pemutlakan ajaran Islam bertanggung jawab terhadap gejala fundamentalisme dewasa ini tidaklah benar sama sekali. Berdasarkan hal ini maka sikap-sikap yang diperankan oleh kelompok fundamentalis tersebut adalah reaksi semata terhadap kepincangan tatanan perpolitikan dunia Internasional terhadap umat Islam.

Djaka Soetapa (1993:6) mencatat bahwa bahaya yang dapat muncul dari gerakan fundamentalisme ialah penampilannya yang eksklusif dalam masyarakat majemuk seperti Indonesia. Jika dalam kemajemukan agama tersebut ditemukan sikap-sikap sebagai yang dimiliki gerakan fundamentalisme di atas, maka secara otomatis akan menimbulkan benturan-benturan yang sulit terbayangkan sebelumnya. Keburukan lain yang ditimbulkan gerakan ini dapat dijelaskan pula sebagai berikut.

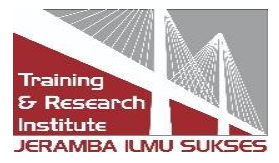


Pertama, fundamentalisme tidak dapat memenuhi harapan manusia, dalam hal hubungan yang lebih serasi antara ilmu dan iman, bahkan lebih meningkatkan polarisasi. Kedua, seharusnya manusia lebih mengupayakan mencari sintesis serta ekuilibrum baru yang seimbang bagi umat manusia, dan bukannya menciptakan konflik-konflik yang mengganggu hubungan antara manusia. Ketiga, metode-metode yang dipakai gerakan fundamentalisme yang eksklusif; indoktrinisasi, fanatisme, pada hakikatnya tidak memanusiakan manusia, sebab tidak membantu menciptakan keserasian hubungan antara manusia dalam masyarakat dan dunia yang semakin pluralistis. Keempat, sikap gerakan fundamentalis yang "anti" atau paling tidak "curiga" terhadap teologi dan kegiatan berteologi, akan menghambat perkembangan teologi dalam upaya menyejahterakan umat manusia (Djaka Soetapa, 1993:6).

Sebenarnya, sebagaimana yang disayangkan oleh Riffat Hassan, pemakaian istilah fundamentalisme atau fundamentalis untuk semua jenis fenomena atau orang adalah sesuatu yang bersifat emosional. Padahal tidak ditemukan alasan logis ataupun teologi orang yang non Nasrani maupun Nasrani sendiri perlu menerima pemakaian kata seperti itu. Sesungguhnya klaim-klaim seperti itu akan semakin menjauhkan aliran pemahaman agama tersebut dari dialog. Klaim-klaim itu justru akan membawa arus radikalisme-destruktif yang deras dari kelompok-kelompok tersebut. Oleh sebab itu maka dehumanusasi yang selalu tertonjol dari sikap kelompok ini seperti terorisme akan semakin menguat. Apalagi adanya kecenderungan pihak Adi Daya untuk mengambil sikap konfrontatif yang akibatkan akan menimbulkan reaksi yang lebih rumit pada masa-masa yang akan datang.

Berdasarkan realitas ini, maka dapat dipastikan bahwa fundamentalis dan fundamentalisme merupakan salah satu agenda yang sedang dihadapi masyarakat agama dan sekaligus masyarakat dunia untuk menyelamatkan umat manusia dari problem disharmonitas dan konflik yang berkepanjangan. Sikap fundamentalis tersebut terdapat dalam keberagaman umat manapun dari ajaran agama apapun.

\section{Penutup}

Pluralisme bangsa Indonesia sesungguhnya dapat juga dipandang sebagai suatu berkah. Karena kemajemukan itu sendiri selain menjadi sumber konflik dan perpecahan, sebenarnya juga berpotensi sebagai sumber kekuatan manakala potensi itu dapat dikelola dan dikembangkan kearah percepatan pencapaian kesejahteraan dan persatuan bangsa.

Keinginan di atas akan lebih cepat terealisasi jika kebijakan mewujudkan kerukunan umat beragama tidak hanya diarahkan pada usaha-usaha dari pihak Islam sementara pihak luar Islam yang nota bene sama "fundamentalisnya" tidak mendapat perhatian penuh bahkan seolah berada pada posisi atau sebagai pihak yang selalu dirugikan.

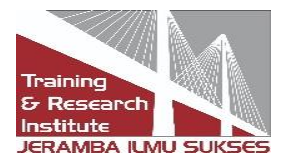




\section{Referensi}

Amin Abdullah dkk., Antologi Studi Islam, Teori dan Metodologi, DIP PTA IAIN Sunan Kalijaga, 2000.

AS. Peak, MA., D.D. et. al. An Outline of Christianity: The Stori of Our Civilization, Vol III, London: The Waverley Book Company, Ltd.

Azyumardi Azra, Memahami Gejala Fundamentalisme, Ulumul Qur'an, NO 3, Vol. IV, 1993.

Bernad Lewis, The Political Language of Islam, University of Chicago Press, 1988.

Djaka Soetapa, Asal Usul Gerakan Fundamentalisme, Ulumul Qur'an, No. 3, Vol. IV, 1993.

Eugne Laverdiers S.S.S., Fundamentalism: A Pastoral Concern dalam The Bible Today, Minnesota, Januari, 1983.

Riffat Hassan, Mempersoalkan Istilah Fundamentalisme Islam, Ulumul Qur'an, NO. 3, Vol. IV, 1993, hlm. 32; Petrick J. Ryan, Islamic Fundamentalism: A Questionable Category, Amerika, 1984.

Rifyal Ka'bah, Modernisme dan Fundamentalisme Ditinjau Dari Konteks Islam, Ulumul Qur'an, No. 3. Vol. IV, 1993.

\section{Copyrights}

Copyright for this article is retained by the author(s), with first publication rights granted to the journal.

This is an open-access article distributed under the terms and conditions of the Creative Commons Attribution license (http://creativecommons.org/licenses/by/4.0/)

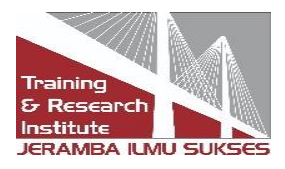

